\title{
Fear of missing out (FoMO) mediate relations between social self-efficacy and life satisfaction
}

\author{
Metin Deniz ${ }^{1,2}$ (B)
}

\begin{abstract}
The purpose of this study was to examine whether fear of missing out (FoMO) mediate relations between social self-efficacy and life satisfaction among undergraduates. The participants involved 323 undergraduates (female, 66.3\%; male, 33.7\%). The age of participants ranged between 18 and 32 years ( $M=21.52, S D=2.69)$. The study data was gathered using the Fear of Missing out Scale, the Social Efficacy and Social Outcome Expectation Scale and the Satisfaction with Life Scale. The research data were analyzed using the structural equation model and bootstrapping method. As a result of the structural equation model, FoMO mediates the relationship between social self-efficacy and life satisfaction. As a result of the bootstrapping analysis, it was seen that all direct and indirect effects are significant. The results, recommendations, and limitations of the study were discussed.
\end{abstract}

Keywords: FoMO, Social self-efficacy, Life satisfaction, Undergraduates, Turkey

\section{Introduction}

Social networks have become an important part of our lives with the developments in technology. Thanks to social communication networks, individuals can receive instant news about what others are doing. Moreover, the individual can keep others informed about what is happening at that moment in his life. The continuous accessibility of social networks provides the opportunity for a significant increase in options for connecting, sharing, and having experiences with acquaintances and friends (Fuster et al., 2017). The individual also meets the need to socialize by making shares on social networks and following the posts made. However, the individual can meet his/her socialization need in unhealthy ways. The need for socialization not met in healthy ways can prepare an environment for the individual to experience FoMO (fear of missing out). FoMO is a concept that is associated with many characteristics of the individual. In

\footnotetext{
Correspondence: metindeniz19@gmail.com

'Department of Educational Sciences, Guidance and Psychological Counseling, Bartin University, Bartin, Turkey

${ }^{2}$ Department of Guidance and Psychological Counseling, Faculty of Education, Bartiın University, Bartin, Turkey
}

this study, the mediating role of FoMO in the relationship between social self-efficacy and satisfaction with life was examined.

\section{Fear of missing out}

Przybylski et al. (2013) associated FoMO with the selfdetermination theory (Deci \& Ryan, 1985), arguing that it arises from the psychological needs of the individual such as autonomy, competence, and relatedness. FoMO is defined as "a pervasive apprehension that others might be having rewarding experiences from which one is absent" (Przybylski et al., 2013, p.1841). This anxiety creates an environment for the individual to stay in touch and communicate with their social environment in order not to miss anything out (Oberst et al., 2017; Wiesner, 2017). The individual constantly desires to be informed about what others are doing now and there, for fear of missing out on developments (Przybylski et al., 2013). The more activities the person can do or situations they can experience, the less likely it is to choose the best option. This situation will cause that person to question how much of his own choice is "the best choice"

\section{Springer Open}

(c) The Author(s). 2021 Open Access This article is licensed under a Creative Commons Attribution 4.0 International License, which permits use, sharing, adaptation, distribution and reproduction in any medium or format, as long as you give appropriate credit to the original author(s) and the source, provide a link to the Creative Commons licence, and indicate if changes were made. The images or other third party material in this article are included in the article's Creative Commons licence, unless indicated otherwise in a credit line to the material. If material is not included in the article's Creative Commons licence and your intended use is not permitted by statutory regulation or exceeds the permitted use, you will need to obtain permission directly from the copyright holder. To view a copy of this licence, visit http://creativecommons.org/licenses/by/4.0/. 
(Milyavskaya et al., 2018). As a result, the person will start to feel anxiety by thinking that there may be potential activities or places other than what they are in (Przybylski et al., 2013). The fear of missing out on developments increases for the individual who experiences this situation intensely.

During university years, individuals leave their families and need to gain a place and exist within the social environment they have established. In particular, university students use social media applications extensively to communicate with their social environment, including their classmates (Ophus \& Abbitt, 2009). This opportunity of internet and social media applications helps university students to feel that they receive social support from their environments such as distant family and friends (Gemmill \& Peterson, 2006).

Studies have demonstrated that FoMO is negatively related to social well-being (Burke et al., 2010), emotional stability, conscientiousness, problematic internet use and well-being (Stead \& Bibby, 2017), psychological need satisfaction, and general mood (Przybylski et al., 2013). On the other hand, FoMO is positively related social media engagement (Przybylski et al., 2013), problematic Instagram use (Balta et al., 2020), problematic smartphone use (Elhai et al., 2020, b), pubbing (Balta et al., 2020), anxiety (Balta et al., 2020; Elhai, Gallinari, et al., 2020; Elhai, Yang, et al., 2020; Holte \& Ferraro, 2020; Wolniewicz et al., 2020), neuroticism (Balta et al., 2020), depression (Elhai, Gallinari, et al., 2020; Holte \& Ferraro, 2020; Wolniewicz et al., 2020), and rumination (Elhai, Yang, et al., 2020).

\section{Social self-efficacy}

Social self-efficacy is defined as an individual's confidence in the ability to participate in social interactive tasks necessary to initiate and maintain interpersonal relationships in his/her social life (Anderson \& Betz, 2001). Social self-efficacy is considered as a necessary skill not only for establishing successful social relationships but also for maintaining mental health (Lin \& Betz, 2009). Social self-efficacy was also associated with personality traits. In the research conducted by Mak and Tran (2001), significant positive relationships were found between social self-efficacy and extraversion, openness and conscientiousness. Therefore, the social self-efficacy of individuals who are open to new experiences and extrovert also increases.

Increased social self-efficacy allows the individual to have courage in establishing social relationships. Moreover, individuals who establish positive social relationships gain experience in establishing social relationships. Individuals with high social self-efficacy can use their problem-solving skills effectively in interpersonal relationships (Erözkan, 2013). Therefore, they can also effectively cope with the problems they encounter in electronic social environments. Individuals who have established successful social relationships expect similar results in their subsequent social relationship experiences (Bakioğlu, 2020;Bakioglu \& Turkum, 2017 ; Wright \& Perrone, 2010).

Studies have demonstrated that social self-efficacy is negatively related academic stress, and interpersonal relationship stress (Chiu, 2014), internet addiction (Bakioğlu, 2020; Gazo et al., 2020; Severino \& Craparob, 2013), loneliness (Bakioğlu, 2020; Gazo et al., 2020) pathological gambling (Passanisi et al., 2020), game addiction (Jeong \& Kim, 2011), online game addiction (Duman \& Ozkara, 2019), accepting external influence, and self-alienating (Satici et al., 2013), depression and shyness (Anderson \& Betz, 2001). On the other hand, social self-efficacy is positively correlated perceived social support (Adams et al., 2019; Bakioğlu, 2020; Traș \& Arslan, 2013), life satisfaction (Bakioglu \& Turkum, 2017; Wright \& Perrone, 2010), authentic living (Satici et al., 2013), and communication skills and interpersonal problem solving skills (Erözkan, 2013). A negative relationship was found between self-efficacy and FoMO (Erdoğan \& Şanll, 2019; Lee et al., 2020). In the literature, there are no research findings that directly address the relationship between social self-efficacy, and FoMO. However, it can be stated that as individuals' social selfefficacy increases, they establish and maintain more satisfying relationships and their FoMO level will decrease.

\section{Satisfaction with life}

Previous researchers considered satisfaction with life as the cognitive component of subjective well-being. Satisfaction with life is an assessment of perceived quality of life (Andrews \& Withey, 1976; Diener et al., 1985) and satisfaction from different areas of life (Myers \& Diener, 1995). In determining the individuals' satisfaction with life, the meaning they attribute to life, happiness in their daily life, harmony to achieve their goals, feeling physically healthy, positive individual identity, security, economic, and social relations are considered important (Schmitter, 2003).

An individual feels satisfaction when a wish, purpose, or need is met in his/her life. The individual's satisfaction enables him/her to feel self-sufficient and to establish and maintain social relationships, to set goals, and to reach certain standards in his life (Dem et al., 2016). Moreover, satisfaction with life is the evaluation of individual on his/her family, friends, social relationships, and the feeling of content with his/her own life (Suldo \& Huebner, 2006). Being happy in daily life of the individual, feeling that life is meaningful, seeing himself/herself sufficient to achieve his/her goals, having good physical health, meeting the needs of his/her socio-economic 
situation, and establishing positive social relationships are determined as effective factors in life satisfaction (Keser, 2005).

Studies have demonstrated that life satisfaction is positively related to self-esteem (Cobos-Sanchiz et al., 2020; Saad, 2020), social self-efficacy (Bakioglu \& Turkum, 2017; Ditchman et al., 2017; Jeon, 2016; Jian et al., 2018; Zamani \& Shirazi, 2020), perceived social support (Cobos-Sanchiz et al., 2020; Malinauskas, 2010), optimism (Oriol et al., 2020; Türküm, 2005), self-control, and positive affection (Oriol et al., 2020). On the other hand, there are negative correlations between life satisfaction and psychological distress (Cobos-Sanchiz et al., 2020; Satici et al., 2020; Zhang et al., 2020), loneliness (Bakioglu \& Turkum, 2017; Mellor et al., 2008), impulsivity, problematic video gaming (Cudo et al., 2020), and negative affectation (Deniz et al., 2012). Studies have shown that as individuals' social self-efficacy increases (starting and maintaining social relationships, etc.), their life satisfaction also increases (Bakioglu \& Turkum, 2017; Ditchman et al., 2017; Jeon, 2016; Jian et al., 2018; Zamani \& Shirazi, 2020). Moreover, life satisfaction was found to be associated with FoMO. Studies have found that FoMO is negatively associated with life satisfaction. As the FoMO level increases, life satisfaction decreases (Can \& Satici, 2019; Giagkou et al., 2018; Hizarcl, 2018; Przybylski et al., 2013; Sette et al., 2020).

\section{Aims}

University years coincide with the young adulthood period. In these years, individuals take steps to establish, strengthen, and maintain long-term social relationships. When the individual realizes that social relations continue outside his/her control while establishing social relationships, they want to be involved in it. They think they may miss new developments when they are not in the same environment with his/her friends. Therefore, the fear of missing out on developments may cause him/ her to try to be more assertive in his/her social relationships and to force his/her friends. All these developments allow the level of FoMO to decrease as the social self-efficacy level of the individual increases. Research results show that there is a negative relationship between social self-efficacy and satisfaction with life, and FoMO. Therefore, as the social efficacy of the individual increases, the FoMO level decreases and satisfaction with life can increase.

In the light of all this information, it can be said that as the social self-efficacy level of university students' increases, their FoMO level decreases and their satisfaction with life increases. Moreover, a negative relationship is expected between social self-efficacy and life satisfaction, and FoMO. A positive relationship is expected between social self-efficacy and life satisfaction. In this study, it was aimed to examine whether FoMO mediates the relationship between social self-efficacy and satisfaction with life.

\section{Hypotheses}

Based on the literature presented, we have put forward the following hypotheses. Each of these hypotheses represents a portion of Fig. 1.

H1. Social self-efficacy will be positively related to life satisfaction.

H2. Social self-efficacy will be negatively related to FoMO.

H3. FoMO will be negatively related to life satisfaction.

H4. The relationships between social self-efficacy and life satisfaction will be mediated by FoMO.

\section{Method}

\section{Participants}

The data were collected through online surveys. It took about 20-25 min for participants to fill in the survey. The data were collected from 323 volunteer undergraduate students at a state university in Turkey. Of all the participants, $214(66.3 \%)$ were females and $109(33.7 \%)$ were males whose ages ranged from 18 to 32 years $(M=$ $21.52, S D=2.69)$. The descriptive information of the participants is presented in Table 1.

\section{Measures \\ Fear of missing out scale}

Fear of missing out of the participants was assessed using the Fear of Missing out Scale (FoMOs; Przybylski

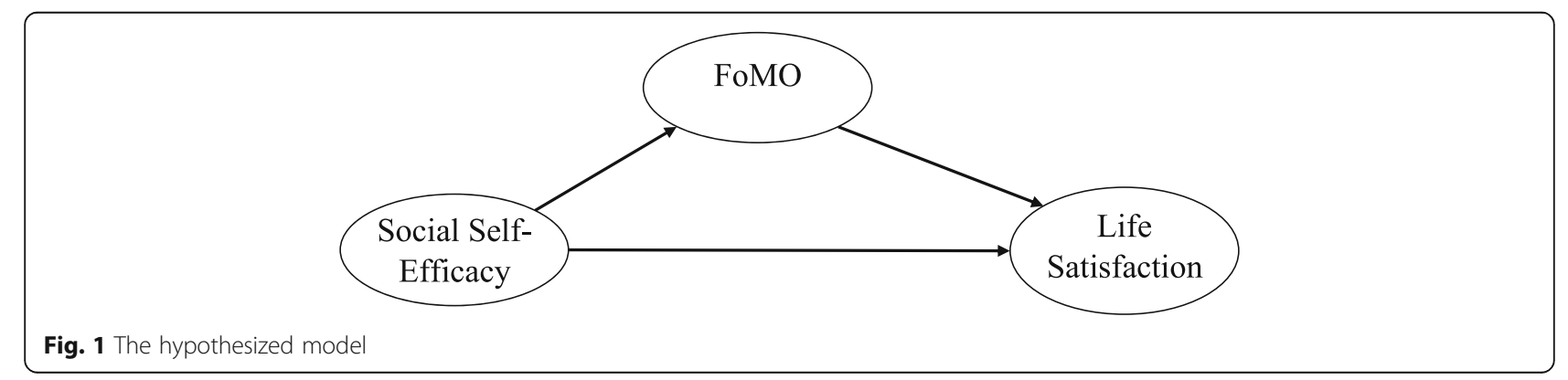


Table 1 Descriptive information of the participants

\begin{tabular}{|c|c|c|}
\hline & Frequency & $\%$ \\
\hline \multicolumn{3}{|l|}{ Gender } \\
\hline Female & 214 & 66.3 \\
\hline Male & 109 & 33.7 \\
\hline \multicolumn{3}{|c|}{ Number of social media accounts } \\
\hline $1-2$ & 137 & 42.4 \\
\hline $3-4$ & 137 & 42.4 \\
\hline 5 and more & 49 & 15.2 \\
\hline \multicolumn{3}{|c|}{ How often to check Facebook notifications during the day } \\
\hline Every $0-30 \mathrm{~min}$ & 134 & 41.5 \\
\hline Every $31-59 \mathrm{~min}$ & 12 & 3.7 \\
\hline Every $1-2 \mathrm{~h}$ & 9 & 2.8 \\
\hline More than $2 \mathrm{~h}$ & 47 & 14.6 \\
\hline Not checking & 40 & 12.4 \\
\hline Does not have an account & 81 & 25.1 \\
\hline \multicolumn{3}{|c|}{ How often to check Twitter notifications during the day } \\
\hline Every $0-30 \mathrm{~min}$ & 86 & 26.6 \\
\hline Every $31-59 \mathrm{~min}$ & 53 & 16.4 \\
\hline Every $1-2 \mathrm{~h}$ & 50 & 15.5 \\
\hline More than $2 \mathrm{~h}$ & 56 & 17.3 \\
\hline Not checking & 17 & 5.3 \\
\hline Does not have an account & 61 & 18.9 \\
\hline \multicolumn{3}{|c|}{ How often to check Instagram notifications during the day } \\
\hline Every $0-30 \mathrm{~min}$ & 52 & 16.1 \\
\hline Every $31-59 \mathrm{~min}$ & 60 & 18.6 \\
\hline Every $1-2 \mathrm{~h}$ & 90 & 27.9 \\
\hline More than $2 \mathrm{~h}$ & 97 & 30.0 \\
\hline Does not have an account & 24 & 7.4 \\
\hline \multicolumn{3}{|c|}{ How often to check YouTube notifications during the day } \\
\hline Every $0-30 \mathrm{~min}$ & 153 & 47.4 \\
\hline Every $31-59 \mathrm{~min}$ & 21 & 6.5 \\
\hline Every $1-2 \mathrm{~h}$ & 39 & 12.1 \\
\hline More than $2 \mathrm{~h}$ & 110 & 34.1 \\
\hline
\end{tabular}

et al., 2013). Participants assess 10 items (e.g., "I fear my friends have more rewarding experiences than me.") on a 5-point Likert-type scale ranging from 1 (not at all true of me) to 5 (extremely true of me), with higher scores indicating higher levels of FoMO. In this study, the Turkish version of the FoMO scale was used (Can \& Satici, 2019). The Turkish version of the FoMO scale internal consistency coefficient $(\alpha=.78)$ and test re-test reliability (.86), was found to be good. Moreover, the construct validity of the scale was found to be excellent $\left(\chi^{2} / d f=1.79, \mathrm{GFI}=.92, \mathrm{CFI}=.90, \mathrm{SRMR}=.006\right.$, and RMSEA = .07; Can \& Satici, 2019). In the present study, the Cronbach's $\alpha$ was good (.81). The construct validity of the scale for present study was found to be excellent $\left(\chi^{2} / d f=2.04, \mathrm{GFI}=.96, \mathrm{CFI}=.97, \mathrm{SRMR}=.04\right.$, and RMSEA $=.05)$.

\section{Social efficacy and social outcome expectation scale}

Social self-efficacy of the participants was assessed using the Social Efficacy and Social Outcome Expectation Scale (SEOES; Wright et al., 2013). Participants assess 19 items (e.g., "I am confident in my skills to be in social relationships" for social efficacy and "Doing nice things for others will increase my social relationships" for social outcome expectation) and two components (social efficacy and social outcome expectation) on a 5-point Likert-type scale ranging from 1 (strongly disagree) to 5 (strongly agree), with higher scores indicating higher levels of social efficacy. In this study, the Turkish version of the SEOES was used (Bakioglu \& Turkum, 2017). The Turkish version of the SEOES internal consistency coefficient ( $\alpha=.92$ for social efficacy, $\alpha=.81$ for social outcome expectation, and $\alpha=.91$ for total) and test re-test reliability (.90), was found to be excellent. Moreover, the construct validity of the scale was found to be excellent $\left(\chi^{2} / d f=2.76\right.$, GFI $=.89$, CFI $=.98$, SRMR $=.02$, and RMSEA = .07; Bakioglu \& Turkum, 2017). In the present study, the Cronbach's $\alpha$ was very good ( $\alpha=.92$ for social efficacy and $\alpha=.77$ for social outcome expectation). The construct validity of the scale for present study was found to be acceptable $\left(\chi^{2} / d f=3.60\right.$, GFI $=.86$, CFI $=$ $.89, \mathrm{SRMR}=.05$, and RMSEA $=.08)$.

\section{Satisfaction with life scale}

The life satisfaction of the participants was assessed using the Satisfaction with Life Scale (SWLS; Diener et al., 1985). Participants assess 5 items (e.g., "The conditions of my life are excellent.") on a 5-point Likert-type scale ranging from 1 (strongly disagree) to 5 (strongly agree), with higher scores indicating higher levels of life satisfaction. In this study, the Turkish version of the SWLS was used (Dağlı \& Baysal, 2016). The Turkish version of the SWLS internal consistency coefficient $(\alpha$ $=.88$ ) and test re-test reliability (.97), was found to be excellent. Moreover, the construct validity of the scale was found to be excellent $\left(\chi^{2} / d f=1.17, \mathrm{GFI}=.99\right.$, AGFI $=.97, \mathrm{CFI}=1.00, \mathrm{NFI}=.99, \mathrm{NNFI}=.1 .00, \mathrm{SRMR}=$ .019 , and RMSEA = .03; Dağlı \& Baysal, 2016). In the present study, the Cronbach's $\alpha$ was good (.78). The construct validity of the scale for present study was found to be excellent $\left(\chi^{2} / d f=1.52, \mathrm{GFI}=.99\right.$, CFI $=.99$, SRMR $=.02$, and RMSEA $=.04)$.

\section{Data analysis}

We carried out the analyzes in two stages. First, we examined normality, reliability, and the relationships between variables. Second, we tested the structural 
equation model. We used the maximum likelihood estimation technique in the structural equation model. In addition, we used the parceling technique to reduce the number of observed variables and to increase reliability and normality (Nasser-Abu Alhija \& Wisenbaker, 2006). We created two parcel for the FoMO scale (Little et al., 2002). We used various fit indices (e.g., $\chi^{2} / d f<5$, CFI, TLI, GFI, IFI > .90, SRMR and RMSEA $<.08, \mathrm{Hu} \&$ Bentler, 1999; MacCallum et al., 1996; Tabachnick \& Fidell, 2007) to evaluate the structural equation model.

In this study, we used bootstrapping analysis for mediation analysis (Preacher and Hayes, 2008). Bootstrapping analysis allows to test whether direct and indirect effects are significant in bigger samples (MacKinnon et al., 2004). In the bootstrapping analysis, 10,000 resampling and $95 \%$ confidence interval (CI) were used. We conducted the analysis of the data by using the $\mathrm{SPSS}^{\circ}$ Statistics 21.00 and IBM SPSS ${ }^{\circ}$ Amos 23.00 software.

\section{Results}

Table 2 displays bivariate descriptive statistics, Pearson correlation coefficients, and reliabilities for the study variables. Social self-efficacy was found to be positively associated with life satisfaction $(r=.42$ and $.34, p<.001)$ (H1) and negatively associated with FoMO ( $r=-.45$ and $-.37, p<.001)(\mathrm{H} 2)$. FoMO was found to be negatively associated with life satisfaction $(r=-.41, p<.001)(\mathrm{H} 3)$. In short, all the variables of the study were significantly associated with each other.

After preliminary analysis, we analyzed the normality assumptions. In the findings, we found that the skewness values ranged from -.52 to .53 , and the kurtosis values ranged from .13 to .31 . We found that the reliability coefficients were above .70 and these values were acceptable. We found that the entire Mahalanobis distance was less than 3 , the variance inflation factor values ranged from 1.28 to 1.57 , the tolerance values ranged from .63 to .69, and the Durbin Watson value was 1.64. All of these results showed that there was no multicollinearity and residual problem and that all of Field's (2016) assumptions were met.

We examined all the path coefficients in the model and found that it was significant. Social self-efficacy predicted life satisfaction positively $(\beta=.42, p<.001)$ (supporting H1) and FoMO negatively $(\beta=-.59, p<.001)$ (supporting H2). In addition, FoMO predicted life satisfaction negatively ( $\beta=-.25, p<.001$ ) (supporting $\mathrm{H} 3$ ). Among the mediation hypotheses, FoMO mediated the relationship between social self-efficacy and life satisfaction, $\beta=-.25, p<.001$ (supporting H4) (Fig. 2).

We examined all fit indices in the structural equation model of the research and found that all of them indicated perfect fit. $\left(\chi^{2}{ }_{(22, N}=323\right)=39.83, p<.001 ; \chi^{2} / d f=$ 1.81; $\mathrm{GFI}=.97 ; \mathrm{CFI}=.98 ; \mathrm{NFI}=.96 ; \mathrm{TLI}=.97$; SRMR $=$ .031 ; RMSEA =.05). All these results show that the hypothetical structural equation model has been validated.

In this study, we tested the mediating role of FoMO in the relationship between social self-efficacy and life satisfaction through bootstrapping procedure. In the bootstrap procedure (coefficients and confidence intervals for direct and indirect effects), we used 10,000 resampling and a 95\% confidence interval (CI). The results obtained are presented in Table 3.

When Table 3 was examined, we saw that all direct effects were significant. We also saw that the indirect effects in the hypothetical model of the research were confirmed [effect $=-.25 ; \mathrm{CI}=(-.40,-.13)]$. According to the results of the bootstrapping analysis, we can say that undergraduate students' social self-efficacy predicts life satisfaction through FoMO.

\section{Discussion}

In this study, the mediating role of FoMO in the relationship between social self-efficacy and satisfaction with life was examined. For this purpose, answers to the hypotheses determined in the study were sought. All path coefficients in the structural equation model of the study were found to be significant (Hu \& Bentler, 1999). Discussion of the research hypotheses is presented below, respectively.

Firstly, a positive relationship was found between social self-efficacy and satisfaction with life (supporting $\mathrm{H1}$ ). Examining the literature, it was seen that studies were supporting a positive relationship between social self-efficacy and satisfaction with life (Bakioglu \& Turkum, 2017; Ditchman et al., 2017;Jeon, 2016 ; Jian et al., 2018 ; Zamani \& Shirazi, 2020). The increase in social self-efficacy of individuals in starting and maintaining social relations also contributes to the development of social relations. It allows individuals with developed

Table $\mathbf{2}$ Correlation matrix of primary study variables

\begin{tabular}{llllllllll}
\hline Variable & $\mathbf{1}$ & $\mathbf{2}$ & $\mathbf{3}$ & $\mathbf{4}$ & $\mathbf{a}$ & $\boldsymbol{M}$ & SD & Skewness & Kurtosis \\
\hline 1. Social efficacy & - & & & .92 & 49.80 & 6.57 & -.52 & .31 \\
2. Social outcome & $.54^{* *}$ & - & & .77 & 24.08 & 2.47 & -.13 & .23 \\
3. FoMO & $-.45^{* *}$ & $-.37^{* *}$ & - & & .81 & 22.83 & 6.16 & .53 & -.13 \\
4. Life satisfaction & $.42^{* *}$ & $.34^{* *}$ & $-.41^{* *}$ & - & .78 & 15.13 & 3.27 & -.13 & -.04 \\
\hline
\end{tabular}

Note. ${ }^{* *}$ Correlation is significant at $p<0.001$ (2-tailed) 


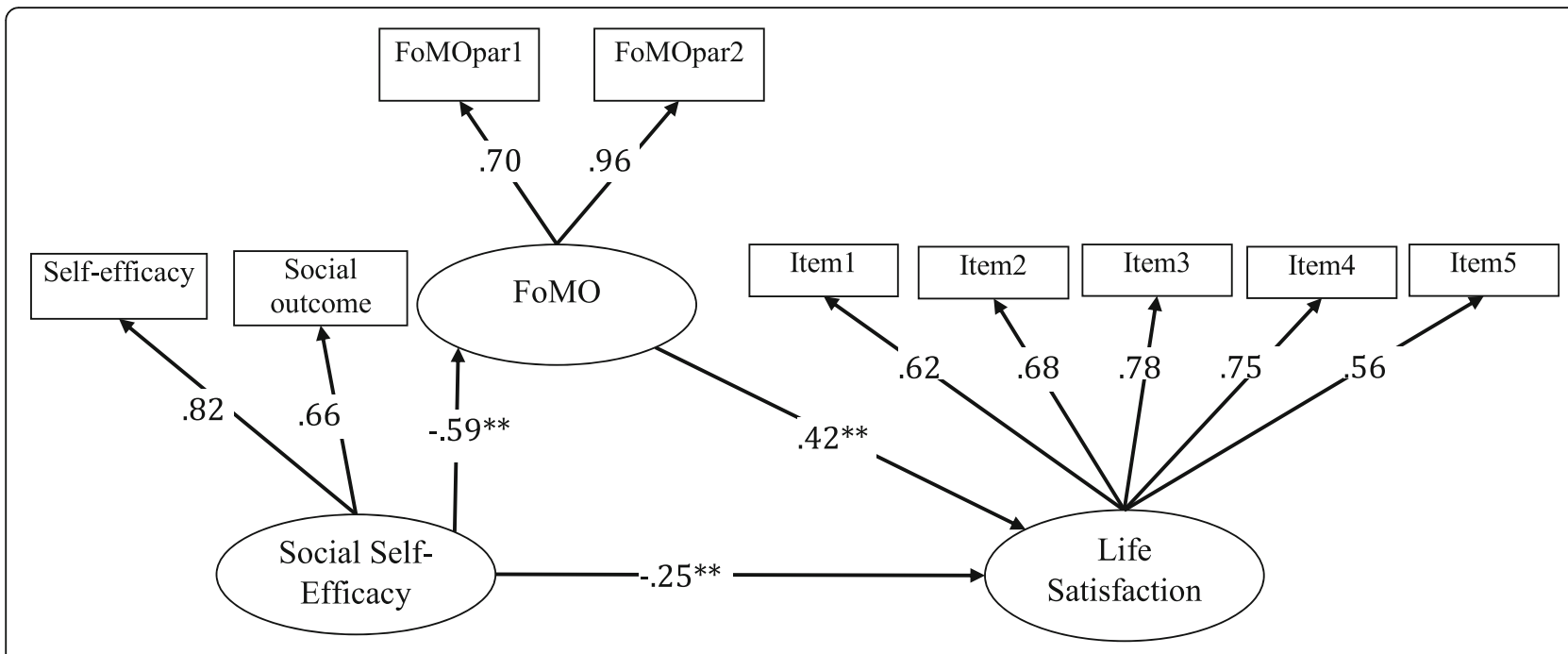

Fig. 2 Mediation for social self-efficacy on life satisfaction via FoMO

social relations to get more satisfaction from their lives and to be happy (Jeon, 2016; Jian et al., 2018; Zamani \& Shirazi, 2020). This finding indicates that as individuals' social self-efficacy increase, their satisfaction with life also increases.

Secondly, a negatively significant relationship was found between social self-efficacy and FoMO (supporting $\mathrm{H} 2$ ). When this finding of the study is evaluated, no research was found in the literature that addresses the relationship between social self-efficacy and FoMO. However, studies examining the relationship between self-efficacy and FoMO have shown a negative relationship between these two variables (Erdoğan \& Şanll, 2019; Lee et al., 2020). Moreover, it is thought that as the social self-efficacy of the individual increases, they may not follow social relationships that they are not involved in. Therefore, the increase in the social selfefficacy of the individual may allow the FoMO level to decrease. As the FoMO level of individuals increases, they spend more time on the Internet and follow what is happening in the virtual environment. When individuals see that they are not included in the activities organized by their acquaintances in virtual environments, they may avoid social relations. Thus, the social self-efficacy of individuals to initiate and maintain social relations may also decrease.

Third of all, a significant negative correlation was found between FoMO and satisfaction with life (supporting H3). Many studies in the related literature show a negative relationship between FoMO and satisfaction with life (Can \& Satici, 2019; Giagkou et al., 2018; Hizarci, 2018; Przybylski et al., 2013; Sette et al., 2020). This finding indicates that as the individual's FoMO level increases, his/her life satisfaction decreases.

Finally, it was discovered that FoMO has a mediating role in the relationship between social self-efficacy and satisfaction with life (supporting H4). When this finding is analyzed, it is seen that the bilateral relationships ( $\mathrm{H} 1$, $\mathrm{H} 2, \mathrm{H} 3$ ) between the variables of the study give significant results. On the other hand, it has been observed that there is no structural equation research directly addressing the relationships between social self-efficacy, satisfaction with life and FoMO, which are discussed in this study. Evaluating the structural equation model of

Table $\mathbf{3}$ Indirect effect of social self-efficacy on life satisfaction via FoMO

\begin{tabular}{llll}
\hline Paths & Coefficient & 95\% C. I. & Low limit \\
\hline Direct effect & & .61 & Up limit \\
$\quad$ Social self-efficacy $\rightarrow$ Life satisfaction & & .42 & -.70 \\
$\quad$ Social self-efficacy $\rightarrow$ FoMO & -.59 & -.41 & -.48 \\
$\quad$ FoMO $\rightarrow$ Life satisfaction & -.25 & -.08 \\
Indirect effect & & -.40 \\
$\quad$ Social self-efficacy $\rightarrow$ FoMO $\rightarrow$ Life satisfaction & -.25 & & -.13 \\
\hline
\end{tabular}


the study, the increase in the social self-efficacy of the individual, which refers to establishment and maintenance of new social relationships, decreases the FoMO, which expresses the anxiety about missing developments (Erdoğan \& Şanll, 2019; Lee et al., 2020) and consequently increases the satisfaction with life (Bakioglu \& Turkum, 2017; Ditchman et al., 2017; Jeon, 2016; Jian et al., 2018; Zamani \& Shirazi, 2020). University years are the times when individuals stay on their own away from their family, but maintain their social relations with their family and friends both in person and in virtual environments (Gemmill \& Peterson, 2006; Ophus \& Abbitt, 2009). The individual becomes less dependent on virtual environments when they meet their basic need for social relationships. Therefore, his/her FoMo level decreases and satisfaction with life increases.

This study investigating the mediating role of FoMo levels in the relationship between university students' social self-efficacy and life satisfaction has some limitations. First of all, this research is a cross-sectional and quantitative research conducted in the structural equation model. It is recommended to conduct research in longitudinal and experimental designs and supported by qualitative research data. Secondly, this research was carried out by a group of university students in Turkey. Therefore, studies can be conducted with larger samples with different cultural characteristics. Another limitation of this study is that $66 \%$ of the study group consisted of women. In future studies, the mean scores of male and female participants can be compared.

Domain experts and practitioners can prepare and implement programs that can increase the social selfefficacy skills of individuals, especially at university ages, in cooperation with universities and non-governmental organizations. Mental health professionals and domain experts can provide protection to individuals from the negative effects of FoMO by preparing psycho-education programs in a preventive context and increasing their skills in initiating and maintaining relationships.

\section{Conclusion}

In this study, it was found that FoMO has a mediating role in the relationship between social self-efficacy and satisfaction with life. Increasing the social self-efficacy of the individual allows him/her to establish and maintain new relationships. Moreover, individuals who establish successful social relationships may prefer to meet this need less in virtual environments. Thus, the door of the individual to be more satisfied with life will be opened by establishing real social relationships. During the times when university students are away from their families, thanks to the real relationships they establish, they can be prepared for life better and contribute to their personal and professional development.

\section{Abbreviations}

FoMOs: Fear of Missing out Scale; SEOES: The Social Efficacy and Social

Outcome Expectation Scale; SWLS: Satisfaction with Life Scale;

$\beta$ : Standardized coefficient

\section{Acknowledgements}

Not applicable.

\section{Author's contributions}

MD designed the model and the computational framework, and analyzed the data. MD read and approved the final manuscript.

Funding

The present submission has not received any funding.

Availability of data and materials

There is no availability of data and materials.

\section{Declarations}

Ethics approval and consent to participate

Informed consent was obtained from all individual participants included in the study. This article does not contain any studies with animals performed by any of the authors.

\section{Competing interests}

The author declares that he has no competing interests.

Received: 4 June 2021 Accepted: 10 August 2021

Published online: 23 August 2021

\section{References}

Adams, S. W., Bowler, R. M., Russell, K., Brackbill, R. M., Li, J., \& Cone, J. E. (2019). PTSD and comorbid depression: Social support and self-efficacy in World Trade Center tower survivors 14-15 years after 9/11. Psychological Trauma Theory Research Practice and Policy, 11(2), 156-164. https://doi.org/10.1037/tra 0000404

Anderson, S. L., \& Betz, N. E. (2001). Sources of social self-efficacy expectations: Their measurement and relation to career development. Journal of Vocational Behavior, 58(1), 98-117. https://doi.org/10.1006/jvbe.2000.1753.

Andrews, F. M., \& Withey, S. B. (1976). Social indicators of well-being: Americans perceptions of life quality. New York: Plenum Press. https://doi.org/10.1007/ 978-1-4684-2253-5.

Bakioğlu, F. (2020). An investigation of perceived social support and social efficacy in university students. OPUS International Journal of Society Researches, 11(18), 1858-1875.

Bakioglu, F., \& Turkum, A. S. (2017). Psychometric properties of adaptation of the social efficacy and outcome expectations scale to Turkish. European Journal of Educational Research, 6(2), 213-223. https://doi.org/10.12973/eu-jer.6.2.213.

Balta, S., Emirtekin, E., Kircaburun, K., \& Griffiths, M. D. (2020). Neuroticism, trait fear of missing out, and phubbing: The mediating role of state fear of missing out and problematic Instagram use. International Journal of Mental Health and Addiction, 18(3), 628-639. https://doi.org/10.1007/s1 1469-018-9959-8.

Burke, M., Marlow, C., \& Lento, T. (2010). Social network activity and social wellbeing. Postgraduate Medical Journal, 85, 455-459.

Can, G., \& Satici, S. A. (2019). Adaptation of fear of missing out scale (FoMOs): Turkish version validity and reliability study. Psicologia: Reflexão e Crítica, 32(1), 3.

Chiu, S. I. (2014). The relationship between life stress and smartphone addiction on Taiwanese university student: A mediation model of learning self-efficacy and social self-efficacy. Computers in Human Behavior, 34, 49-57. https://doi. org/10.1016/j.chb.2014.01.024.

Cobos-Sanchiz, D., Del-Pino-Espejo, M. J., Sánchez-Tovar, L., \& Matud, M. P. (2020). The importance of work-related events and changes in psychological distress and life satisfaction amongst young workers in Spain: A gender analysis. International Journal of Environmental Research and Public Health, 17(13), 4697. https://doi.org/10.3390/ijerph17134697.

Cudo, A., Wojtasiński, M., Tużnik, P., Griffiths, M. D., \& Zabielska-Mendyk, E. (2020). Problematic Facebook use and problematic video gaming as mediators of relationship between impulsivity and life satisfaction among female and 
male gamers. PLoS One, 15(8), e0237610. https://doi.org/10.1371/journal.pone. 0237610.

Dağlı, A., \& Baysal, N. (2016). Adaptation of the satisfaction with life scale into Turkish: The study of validity and reliability. Electronic Journal of Social Sciences, 15(59), 1250-1262.

Deci, E., \& Ryan, R. M. (1985). Intrinsic motivation and self-determination in human behavior. New York: Plenum Press. https://doi.org/10.1007/978-1-4899-2271-7.

Dem, U., Swartz, M., Mirecki, I., \& Barak, Y. (2016). Physicians' life satisfaction in Bhutan: A nationwide survey. Open Journal of Psychiatry, 6(1), 119-124. https://doi.org/10.4236/ojpsych.2016.61014.

Deniz, M. E., Arslan, C., Özyeşil, Z., \& İmirli, M. (2012). Self-compassion, life satisfaction, negative and positive affect: A comparison between Turkey and other different countries' university students. Mehmet Akif Ersoy University Journal of Education Faculty, 12(23), 428-446.

Diener, E. D., Emmons, R. A., Larsen, R. J., \& Griffin, S. (1985). The satisfaction with life scale. Journal of Personality Assessment, 49(1), 71-75. https://doi.org/10.12 07/s15327752jpa4901_13.

Ditchman, N., Sung, C., Easton, A. B., Johnson, K. S., \& Batchos, E. (2017). Symptom severity and life satisfaction in brain injury: The mediating role of disability acceptance and social self-efficacy. NeuroRehabilitation, 40(4), 531-543. https://doi.org/10.3233/NRE-171440.

Duman, H., \& Ozkara, B. Y. (2019). The impact of social identity on online game addiction: The mediating role of the fear of missing out (FoMO) and the moderating role of the need to belong. Current Psychology, 1-10.

Elhai, J. D., Gallinari, E. F., Rozgonjuk, D., \& Yang, H. (2020). Depression, anxiety and fear of missing out as correlates of social, non-social and problematic smartphone use. Addictive Behaviors, 105, 106335. https://doi.org/10.1016/j.a ddbeh.2020.106335

Elhai, J. D., Yang, H., Rozgonjuk, D., \& Montag, C. (2020). Using machine learning to model problematic smartphone use severity: The significant role of fear of missing out. Addictive Behaviors, 103, 106261. https://doi.org/10.1016/j.a ddbeh.2019.106261

Erdoğan, P., \& Şanlı, Y. (2019). The effects of general self-efficacy on fear of mising out of faculty of health sciences students. OPUS International Journal of Society Researches, 14(20), 596-620. https://doi.org/10.26466/ opus.595661.

Erözkan, A. (2013). The effect of communication skills and interpersonal problem solving skills on social self-efficacy. Educational Sciences: Theory and Practice, 13(2), 739-745.

Field, A. (2016). Discovering statistics using IBM SPSS Statistics. London: Sage.

Fuster, H., Chamarro, A., \& Oberst, U. (2017). "Fear of missing out, online social networking and mobile phone addiction: A latent profile approach", Revista de Psicologia. Ciències de l'Educació $i$ de l'Esport, 35(1), 23-30.

Gazo, A. M., Mahasneh, A. M., Abood, M. H., \& Muhediat, F. A. (2020). Social selfefficacy and its relationship to loneliness and internet addiction among Hashemite University students. International Journal of Higher Education, 9(2), 144-155. https://doi.org/10.5430/ijhe.v9n2p144.

Gemmill, E. L., \& Peterson, M. (2006). Technology use among college students: Implications for student affairs professionals. Journal of Student Affairs Research and Practice, 43(2), 482-502.

Giagkou, S., Hussain, Z., \& Pontes, H. M. (2018). Exploring the interplay between passive following on Facebook, fear of missing out, self-esteem, social comparison, age, and life satisfaction in a community-based sample. International Journal of Psychology \& Behavior Analysis, 4(149), 1-6. https://doi. org/10.15344/2455-3867/2018/149.

HIzarcI, Ö. (2018). An examination of the relationship between problematic cell phone use, fearing of missing out, life satisfaction and attachment styles in terms of demographic variables, Unpublished master thesis (). İstanbul: Üsküdar University.

Holte, A. J., \& Ferraro, F. R. (2020). Anxious, bored, and (maybe) missing out: Evaluation of anxiety attachment, boredom proneness, and fear of missing out (FoMO). Computers in Human Behavior, 112, 106465. https://doi.org/10.1 016/j.chb.2020.106465.

Hu, L. T., \& Bentler, P. M. (1999). Cutoff criteria for fit indexes in covariance structure analysis: Conventional criteria versus new alternatives. Structural Equation Modeling: A Multidisciplinary Journal, 6(1), 1-55. https://doi.org/10.1 080/10705519909540118.

Jeon, H. O. (2016). The influence of nursing professionalism, academic failure tolerance and social self-efficacy on college life satisfaction among nursing students. The Journal of Korean Academic Society of Nursing Education, 22(2), 171-181. https://doi.org/10.5977/jkasne.2016.22.2.171.
Jeong, E. J., \& Kim, D. H. (2011). Social activities, self-efficacy, game attitudes, and game addiction. Cyberpsychology, Behavior and Social Networking, 14(4), 213221. https://doi.org/10.1089/cyber.2009.0289.

Jian, C., Yiran, Z., Chen, C.. \& Kan, S. (2018). Social exclusion and life satisfaction: The effect of social self-efficacy and social support. Management Review, 30(9), 256.

Keser, A. (2005). Iş doyumu ve yaşam doyumu ilişkisi: Otomotiv sektöründe bir uygulama [Job satisfaction and life satisfaction relationship: An application in the automotive industry]. Labour and Society, 4(7), 77-96.

Lee, K. H., Lin, C. Y., Tsao, J., \& Hsieh, L. F. (2020). Cross-sectional study on relationships among FoMO, social influence, positive outcome expectancy, refusal self-efficacy and SNS usage. International Journal of Environmental Research and Public Health, 17(16), 5907. https://doi.org/10.3390/ijerph171 65907.

Lin, S. P., \& Betz, N. E. (2009). Factors related to the social self-efficacy of Chinese international students. The Counseling Psychologist, 37(3), 451-471. https://doi. org/10.1177/0011000009332474

Little, T. D., Cunningham, W. A., Shahar, G., \& Widaman, K. F. (2002). To parcel or not to parcel: Exploring the question, weighing the merits. Structural Equation Modeling, 9(2), 151-173. https://doi.org/10.1207/S1532 8007SEM0902_1.

MacCallum, R. C., Browne, M. W., \& Sugawara, H. M. (1996). Power analysis \& determination of sample size for covariance structure modeling. Psychological Methods, 1(2), 130-149. https://doi.org/10.1037/1082 989X.1.2.130.

Mackinnon, D. P., Lockwood, C. M., \& Williams, J. (2004). Confidence limits for the indirect effect: Distribution of the product and resampling methods. Multivariate Behavioral Research, 39(1), 99-128. https://doi.org/10.1207/s1532 $7906 \mathrm{mbr} 3901$ 4.

Mak, A. S., \& Tran, C. (2001). Big five personality and cultural relocation factors in Vietnamese Australian students' intercultural social self-efficacy. International Journal of Intercultural Relations, 25(2), 181-201. https://doi.org/10.1016/5014 $7-1767(00) 00050-X$

Malinauskas, R. (2010). The associations among social support, stress, and life satisfaction as perceived by injured college athletes. Social Behavior and Personality: An International Journal, 38(6), 741-752. https://doi.org/10.2224/ sbp.2010.38.6.741

Mellor, D., Stokes, M., Firth, L., Hayashi, Y., \& Cummins, R. (2008). Need for belonging, relationship satisfaction, loneliness, and life satisfaction. Personality and Individual Differences, 45(3), 213-218. https://doi.org/10.1016/j.paid.2008. 03.020 .

Milyavskaya, M., Saffran, M., Hope, N., \& Koestner, R. (2018). Fear of missing out: Prevalence, dynamics, and consequences of experiencing FOMO. Motivation and Emotion, 42(5), 725-737. https://doi.org/10.1007/s11031-018-9683-5.

Myers, D. G., \& Diener, E. (1995). Who is happy? Psychological Science, 6(1), 10-19. https://doi.org/10.1111/j.1467-9280.1995.tb00298.x.

Nasser-Abu Alhija, F., \& Wisenbaker, J. (2006). A Monte Carlo study investigating the impact of item parceling strategies on parameter estimates and their standard errors in CFA. Structural Equation Modeling, 13(2), 204-228. https:/ doi.org/10.1207/s15328007sem1302_3.

Oberst, U., Wegmann, E., Stodt, B., Brand, M., \& ve Chamarro, A. (2017). Negative consequences from heavy social networking in adolescents: The mediating role of fear of missing out. Journal of Adolescence, 55, 51-60. https://doi.org/1 0.1016/j.adolescence.2016.12.008.

Ophus, J. D., \& Abbitt, J. T. (2009). Exploring the potential perceptions of social networking systems in university courses. Journal of Online Learning and Teaching, 5(4), 639-648.

Oriol, X., Miranda, R., Bazán, C., \& Benavente, E. (2020). Distinct routes to understand the relationship between dispositional optimism and life satisfaction: Self-control and grit, positive affect, gratitude, and meaning in life. Frontiers in Psychology, 11, 907. https://doi.org/10.3389/fpsyg.2020.00907.

Passanisi, A., D'Urso, G., Schimmenti, A., Ruggieri, S., \& Pace, U. (2020). Coping strategies, creativity, social self-efficacy, and hypercompetitiveness in gambling behaviors: A study on male adolescent regular gamblers. Frontiers in Psychology, 11, 1722. https://doi.org/10.3389/fpsyg.2020.01722.

Preacher, K. J., \& Hayes, A. F. (2008). Asymptotic and resampling strategies for assessing and comparing indirect effects in multiple mediator models. Behavior Research Methods, 40(3), 879-891.

Przybylski, A. K., Murayama, K., DeHaan, C. R., \& Gladwell, V. (2013). Motivational, emotional, and behavioral correlates of fear of missing out. Computers in Human Behavior, 29(4), 1841-1848. https://doi.org/10.1016/j.chb.2013.02.014. 
Saad, J. (2020). Self-esteem and life satisfaction amongst Afghan and Indian University students. International Journal of Creative Research Thoughts (IJCRT), 2320-2882

Satici, B., Gocet-Tekin, E., Deniz, M. E., \& Satici, S. A. (2020). Adaptation of the fear of COVID-19 scale: Its association with psychological distress and life satisfaction in Turkey. International Journal of Mental Health and Addiction, 1.

Satici, S. A., Kayis, A. R., \& Akin, A. (2013). Investigating the predictive role of social self-efficacy on authenticity in Turkish university students. Europe's Journal of Psychology, 9(3), 572-580. https://doi.org/10.5964/ejop.v9i3.579.

Schmitter, C. (2003). Life satisfaction in centenarians residing in long-term care. http://www.mmhc.com/articles/NHM9912/cutillo.html

Sette, C. P., Lima, N. R., Queluz, F. N., Ferrari, B. L., \& Hauck, N. (2020). The online fear of missing out inventory (ON-FoMO): Development and validation of a new tool. Journal of Technology in Behavioral Science, 5(1), 20-29. https://doi. org/10.1007/s41347-019-00110-0.

Severino, S., \& Craparob, G. (2013). Internet addiction, attachment styles, and social self-efficacy. Global Journal of Psychology Research, 3(1), 9-16.

Stead, H., \& Bibby, P. A. (2017). Personality, fear of missing out and problematic internet use and their relationship to subjective well-being. Computers in Human Behavior, 76, 534-540. https://doi.org/10.1016/j.chb.2017.08.016.

Suldo, S., \& Huebner, S. (2006). Is extremely high life satisfaction during adolescence advantageous? Social Indicators Research, 78(2), 179-203. https:// doi.org/10.1007/s11205-005-8208-2.

Tabachnick, B. G., \& Fidell, L. S. (2007). Using multivariate statistics. Boston: Pearson.

Trass, Z., \& Arslan, E. (2013). An investigation of perceived social support and social self efficacy in adolescents. Elementary Education Online, 12(4), 1133-1140.

Türküm, A. S. (2005). Do optimism, social network richness and submissive behaviors predict well-being? Study with a Turkish sample. Social Behavior and Personality, 33(6), 619-628. https://doi.org/10.2224/sbp.2005.33.6.619.

Wiesner, L. (2017). Fighting FoMO: A study on implications for solving the phenomenon of the fear of missing out, Master's thesis (). University of Twente.

Wolniewicz, C. A., Rozgonjuk, D., \& Elhai, J. D. (2020). Boredom proneness and fear of missing out mediate relations between depression and anxiety with problematic smartphone use. Human Behavior and Emerging Technologies, 2(1), 61-70. https://doi.org/10.1002/hbe2.159.

Wright, S. L., \& Perrone, K. M. (2010). An examination of the role of attachment and efficacy in life satisfaction. The Counseling Psychologist, 38(6), 796-823. https://doi.org/10.1177/0011000009359204.

Wright, S. L., Wright, D. A., \& Jenkins-Guarnieri, M. A. (2013). Development of the social efficacy and social outcome expectations scale. Measurement and Evaluation in Counseling and Development, 46(3), 218-231. https://doi.org/1 $0.1177 / 0748175613484042$.

Zamani, B., \& Shirazi, M. (2020). Predictions social self-efficacy and life satisfaction in students through attachment to parents and peers. Journal of Educational Psychology Studies, 17(38), 67-84. https://doi.org/10.22111/jeps.2020.5278.

Zhang, S. X., Wang, Y., Rauch, A., \& Wei, F. (2020). Unprecedented disruption of lives and work: Health, distress and life satisfaction of working adults in China one month into the COVID-19 outbreak. Psychiatry Research, 112958.

\section{Publisher's Note}

Springer Nature remains neutral with regard to jurisdictional claims in published maps and institutional affiliations.

\section{Submit your manuscript to a SpringerOpen ${ }^{\odot}$ journal and benefit from:}

- Convenient online submission

- Rigorous peer review

- Open access: articles freely available online

- High visibility within the field

- Retaining the copyright to your article

Submit your next manuscript at $\boldsymbol{\nabla}$ springeropen.com 